ABORIGINAL USE OF MINERAL COAL AND. ITS DISCOVERY IN THE WEST.

BY CFARLES R. KEYES.

There is little record of the extensive use of mineral products by the Indians of this country at the time of its discovery. In the normal course of national development, the use of large fuel supplies belongs to a period when a country has, become thickly populated, when the arts and manufacturing enterprises attain great importance, and commerce assumes large proportions. In America, however, mineral coal as a fuel appears to have been known at a very early day. How long before the advent of the European it was used is largely a matter of conjecture. Strangely enough its discovery belongs to the interior of the continent rather than to the Atlantic seaboard, where the first permanent European settlement took place, where it is now so extensively mined, and where it is known to be so widely distributed. In the continental interior the discovery of coal antedates that of the East by at least half a century; while in a limited way to be sure, its use by the Indians is now known to go back to a still more remote period.

Relying upon general history the discovery of mineral coal in America dates back to the beginning of the eighteenth century. - The earliest record in Pennsylvania is 1704, twenty years after the privilege of colonization was granted by Charles II. to Penn. Anthracite was first known in the Wyoming district of Pennsylvania in 1766 ; and its discovery in the Lehigh valley took place twenty-five years later. Virginia coals appear to have been mined for the first time near Richmond in 1750; and at the close of the Revolutionary war they were shipped from this region to Philadelphia, New York. and Boston. 
In this country the earliest definite mention of the existence of mineral fuel in the form of coal appears to be in the Upper Mississippi region. Jesuit missionaries in the Assiniboine land, then in what is the State of Minnesota of today, make record of the occurrence of coal as early as 1659 . In describing the Poualak (Assiniboine tribes) this statement occurs: "Comme le bois est rare \& petit chez eux, la nature leur a appris à faire du feu avec du charbon de terre, \& a couvrir leurs cabanes avec des peaux. . . . ."* It is also quite possible that the Ioway Indians of the northern prairies also made use of the lignite deposits of the region such as are found, for example, in Brown county, Minnesota, near the headwaters of the Des Moines river, and on the Big Sioux river in Plymouth county, Iowa.

When LaSalle established, in 1860, Fort Crève Cœur on the Illinois river near the present site of Peoria, large coal beds were found and used. Father Hennepin, who was associated with LaSalle, states in the journal of his travels, that at the place mentioned mineral coal exists. In an English edition of his map of the Upper Mississippi region the location is clearly represented.* That he was not in any way mistaken is amply shown by subsequent developments.

In his letters regarding the natural productions found along the Illinois river, written a few years later, La Salle also mentions the fact of the occurrence of coal at Crève Cœur. These letters were recently reprinted in Paris by Margry.* The following paragraph has a special interest in this connection: "Il y a aussy quantité d'ardoisieres et charbon de terre; quatre lieues plus bas, a droite, on trouve la rivière des Pestigouki dans laquelle $j$ 'ay trouve un morceau de cuivre et

- Relation de ce qui s'est Passé de plvs Remarkable avx missions des Péres de la Compagnie de Jésus en la Novvelle France, en années six cent suixante enuoyée au R. P. Clvde Bavches, A Paris, Sebastien six "As wood is scarce and very small with them nature has taught them to burn coal in its place, and to cover their wigwams with skins."

*New Discovery of a Vast Country in America, etc., English ed., map, London, 1898 .

- Mém. et doc. pour servir la l'histoire des origines Francalses des pays d'outre-mere; $t$. II, Lettres de Cavelier de la salle et correspondance relative a ses entreprises (1676-1685), p. 175, Paris, 1879. 
une espece de metal que j'envoyay, il y a deuxans, a $M$. de Frontenac dont je n'ay point en de respouse, et que je croy de la bronze, si elle se trouve en mine."

Still another very early reference to the occurrence of coal in the Upper Mississippi valley is that of Le Gardeur de l'Isle, who writes in 1722 from Fort Chartres, near Kaskaskia, that he accompanied one De Renault to the Illinois river to look after copper and coal mines.*

The French early knew of the existence of coal which outcropped on the Missouri river near its mouth, at a point called La Charbonnière. Nearly a century later, in. 1805, Pike, when he started on his famous trip to the sources of the Arkansas river, passed the place. He says: "Six miles below St. Charles, on the south side, in front of a village called Florissant, is a cọal hill, or as it is termed by the French, La Charbonnière. This is one solid sandstone hill which probably affords sufficient fuel for all the population of Louisiana."

Long on his expedition from Pittsburg to the Rocky mountains, in 1819, also visited Charbonnière." He also noted other coal deposits in going overland in a direct line from the mouth of the Missouri river to Council Bluffs. "The Chariton river originates near the De Moyen river of the Mississippi and traverses the region which is of great importance both on account of the fertility of its soil and its inexhaustible mines of coal. . . These extensive beds of coal will be considered of great value and the necessities of the inhabitants will lead to their early explorations." "*

The first distinct mention of the occurrence of mineral coal in Iowa appears to be that of Featherstonhaugh, * who in 1835 descended the Mississippi river in a canoe, from Dubuque to St. Louis. At the mouth of Rock river, on both

*Coll: Wisconsin State Hist. Soc., Vol. XIII, p. 275, 1888.

*Explorations to Sources of Mississippi, etc., during 1805, 1806, and 1807, pt. ii, p. 126, Philadelphia, 1810.

*Exp. Pittsburg to Rocky Mts., etc., Vol. I, p. 70, 1823.

*Ibia., p. 97.

*Rept. Geol. Reconnaissance, etc., to Coteau de Prairie, p. 129, Washington, 1836 . 
sides of the Mississippi, he reports the occurrence of bituminous coal deposits.

The same year Albert Lea investigated for the Federal government the resources of the Black Hawk Purchase,* comprising the present eastern Iowa, and noted the occurrence of coal in many places. In the Des Moines valley he records large coal deposits existing between the mouth of that river and the Raccoon forks. *

\footnotetext{
*Notes on Wisconsin Terr., particularly with Reference to Iowa Dist. or Black Hawk Purchase, 53 pp., Philadelphia, 1836.

*Ibid., p. 25.
}

\section{STEAM FERRY}

FROM

\section{FORT MADISON TO APANOOSE.}

The undersigned have recently purchased of Mr. Edward White, the above ferrying privilege and Boat, the latter of which during the last fall has underwent a thorough repair being almost entirely constructed; the engine has been so altered as to very much increase her speed, in short the whole has been rendered much more safe and expeditious than it formerly was.

This ferry is the nearest and on almost the entire accessible route to Ft. Madison or the Des Moines country, this being the only point in the south part of the Territory free from inundation. The public need not fear double charges as is the ease at other places as we have but one price which is fixed by law and we are determined that the public shall not be disappointed with the want of exertion on our part. The Boat: will remain at each landing only 15 minutes going and returning.

\section{BILL OF FARE.}

For each wagon and two horses or oxen including the persons

and baggage actually belonging the same............. $\$ 1.00$

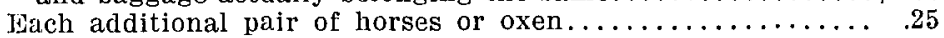

Wach wagon or cart and one horse including the persons and

baggage actually belonging to the same..............75

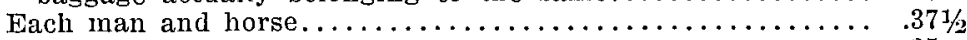

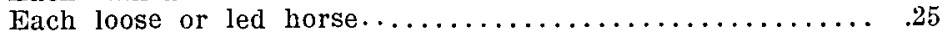

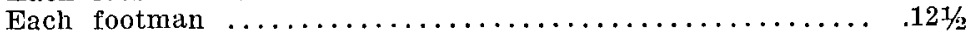

Each head of loose cattle $\ldots \ldots \ldots \ldots \ldots \ldots \ldots \ldots \ldots \ldots \ldots .121 \%$

Each head of sheep, hogs, etc .......................

MCCARVER, WHITE \& DOOLITTLE

- Iowa Territorial Gazette and Burlington Advertiser, Burlington,

I. T., March 28, 1840 . 
Copyright of Annals of Iowa is the property of State of Iowa, by \& through the State Historical Society of Iowa and its content may not be copied or emailed to multiple sites or posted to a listserv without the copyright holder's express written permission. However, users may print, download, or email articles for individual use. 